\title{
Can International Patent Law Help Mitigate Cancer Inequity in LMICs?
}

Srividhya Ragavan

Texas A\&M University School of Law, ragavan.sri@law.tamu.edu

Amaka Vanni

Follow this and additional works at: https://scholarship.law.tamu.edu/facscholar

Part of the Health Law and Policy Commons, Intellectual Property Law Commons, and the International Law Commons

\section{Recommended Citation}

Srividhya Ragavan \& Amaka Vanni, Can International Patent Law Help Mitigate Cancer Inequity in LMICs?, 22 AMA J. Ethics 102 (2020).

Available at: https://scholarship.law.tamu.edu/facscholar/1365

This Article is brought to you for free and open access by Texas A\&M Law Scholarship. It has been accepted for inclusion in Faculty Scholarship by an authorized administrator of Texas A\&M Law Scholarship. For more information, please contact aretteen@law.tamu.edu. 


\title{
AMA Journal of Ethics ${ }^{\circledR}$
}

\section{February 2020, Volume 22, Number 2: E102-111}

\author{
HEALTH LAW
}

\section{Can International Patent Law Help Mitigate Cancer Inequity in LMICs?}

Srividya Ragavan, SJD and Amaka Vanni, PhD

\begin{abstract}
Although low- and middle-income countries (LMICs) bear 75\% of the cancer burden globally, their available resources to treat cancer constitute less than $5 \%$ of global health resources. This inequity makes it imperative to take appropriate measures to treat and prevent cancer in LMICs, which should include consideration of trade and patent policies. This article highlights some impediments to effective use of existing policies to promote access to treatment and prevention measures in LMICs and offers recommendations about next steps.
\end{abstract}

\section{Introduction}

Cancer incidence is rising globally, resulting in financial, physical, and emotional distress to families and burdening public health services. According to the World Health Organization (WHO), the global cancer burden was estimated to have risen from 14.1 million new cases in 2012 to 18.1 million new cases in 2018 and from 8.2 million deaths in 2012 to 9.6 million deaths in 2018. ${ }^{1}$ Low- and middle-income countries (LMICs) bear $75 \%$ of cancer deaths. ${ }^{2}$ Asia and Africa, for example, have a higher proportion of cancer deaths $(7.3 \%$ and $57.3 \%$, respectively) compared to their incidence $(5.8 \%$ and $48.4 \%$, respectively) than other countries due, in part, to enormous inequities in cancer treatment. ${ }^{3}$ Indeed, the available resources to treat cancer in LMICs compose less than $5 \%$ of the global share of resources for cancer control. ${ }^{4}$ Correspondingly, only $10 \%$ of children diagnosed with cancer in LMICs are cured compared with more than $80 \%$ of such children in high-income countries. ${ }^{4} \mathrm{~A}$ WHO finding that less than $30 \%$ of low-income countries report having treatment services available compared to more than $90 \%$ of highincome countries underscores the enormous inequities in cancer treatment and access to cancer medications. ${ }^{5}$ These disparities make it critical to focus cancer control efforts on LMICs. 
In these countries, many new cancer medications are exorbitantly expensive relative to individual income. For example, one company's egregious original price tag of Rs 280428 per month (about $\$ 5000$ at that time) for sorafenib tosylate, a drug for treating primary kidney cancer and advanced liver cancer, was nearly 5 times higher than the median annua/income in India. ${ }^{6}$ Like this drug, many cancer drugs are unaffordable for large number of patients diagnosed with cancer in poorer nations.

Efforts to effectively improve access to medicines by reducing costs of cancer medications should look to international trade agreements and, particularly, TRIPS flexibilities for compulsory license (explained below), which can (and should) be used to address health burdens, such as the HIV/AIDS epidemic. Just as in the case of an epidemic, efforts to address cancer should be mindful of the labor and economic loss that ensue when productive individuals are lost to disease. In order to be involved effectively in such efforts, the medical community must appreciate how international trade and patent prescriptions intersect with efforts to improve access to cancer medication, especially in LMICs where such access remains inadequate. The focus of this essay, therefore, is on how international patent law can help mitigate the cancer burden in LMICs.

\section{Global Trade Policies and Cancer}

The inclusion of intellectual property (hereafter, IP) within the global trade framework ${ }^{7}$ was a defining moment for global access to medication. In broad terms, IP rights are legal tools designed to result in public benefit by promoting private rights. Thus, IP rights recognize innovations by awarding monopoly rights to the creator as a means to incentivize creativity. In 1995, when the Agreement on Trade-Related Aspects of Intellectual Property Rights (TRIPS agreement), ${ }^{8}$ which forms a part of the larger World Trade Organization (WTO), ${ }^{9}$ became effective, it required all member states to provide a 20-year term of protection for all pharmaceutical innovations. The TRIPS agreement provided limited flexibilities for countries to weigh IP rights against public health and developmental needs. ${ }^{8}$ Specifically, Article 31 of the TRIPS agreement allows for compulsory license, a mechanism that permits a third party to produce a patented product or process without the consent of the patent owner. The patent owner still retains the right to the patent and receives royalties for the products made under the compulsory licence. However, this provision allows a sovereign government to authorize the licensing of a patent to produce a generic version of the drug, enabling greater access to it during a public health crisis. 
Nevertheless, the inadequacies of the compulsory license during global public health crises - particularly the HIV/AIDS crisis - forced member states to adopt, in 2001, the Doha Declaration on the TRIPS Agreement and Public Health. The Doha Declaration affirms the right of member states to implement policies to enable access to medicines to address a national public health crisis. ${ }^{10}$ Thus, Article 31 of the TRIPS agreement in conjunction with the Doha Declaration reaffirms the rights of sovereign nations to "protect public health and enhance access to medicines." ${ }^{11}$ Importantly, while the Doha Declaration reaffirmed member countries' ability to compulsorily license a patent for the production of generic drugs to address a public health crisis, it underscored the existence of member countries that are unable to take advantage of the compulsory license because they lack the manufacturing capabilities to even produce generic medications. Hence, the WTO General Council, in 2005, adopted Article 31(bis), ${ }^{12}$ which allows for export of generic drugs from member countries that can produce licensed medication to member countries that lack manufacturing facilities but need the medication. Through this provision, the TRIPS agreement allows nations to act either individually or as a regional group in granting compulsory licenses to export pharmaceutical products to member countries with insufficient or no manufacturing capacities. However, the definition of what constitutes a national public health crisis has remained contentious. ${ }^{13}$

To date, there has been limited use of compulsory licenses for cancer drugs. In fact, only 2 countries have issued compulsory licenses for cancer treatment to reduce the cost of medication. India's first (and so far only) compulsory license was for sorafenib, a drug to treat kidney cancer, ${ }^{14}$ and Thailand granted compulsory licenses over 3 cancer medications: erlotinib (for small cell lung cancer), letrozole (for early breast cancer) and docetaxel (for breast cancer). ${ }^{15}$ Both countries cited the high cost of the patented drugs as the reason for issuing compulsory licenses to improve access to these medicines in their patient population. ${ }^{16}$

Despite their limited use, compulsory licenses in these countries were hugely contentious. ${ }^{17}$ Specifically, both countries were unilaterally targeted by the United States through the Special 301 process, which identifies nations whose domestic IP laws and policies are perceived as creating market access barriers to US business interests. As a result, India and Thailand have featured in the Priority Watch Lists compiled annually by the Office of the US Trade Representative under Section 301 of the Trade Act of 1974 for having instituted legitimate health safeguards. ${ }^{18}$ Unilateral US actions have been on 
shaky legal grounds because the trade regime only provides for multilateral dispute settlement. That the United States, as a rule, unilaterally forces trade concessions from countries using negotiated flexibilities to alleviate a public health crisis has resulted in interventions by the WHO and the United Nations ${ }^{19}$ in favor of countries that lack the same bargaining power as the United States. Nevertheless, US actions have made countries hesitant to use compulsory licenses to increase access by lowering the cost of cancer medications. ${ }^{20}$

Notwithstanding the TRIPS agreement's provision for compulsory licenses, other impediments from patent policies have stymied efforts to provide access to medication. Some examples of pharmaceutical patent-related impediments include evergreening ${ }^{21}$ and the cost and use of public funds to create private property. ${ }^{22}$ Additionally, barriers to competition from follow-on products during the postpatent period include provisions for data and market exclusivity for clinical trial data and provisions that act as a barrier to national interventions. ${ }^{23}$ The following section discusses 2 issues that most affect access to cancer medications: data and market exclusivity provisions that affect national interventions (eg, preventive measures).

\section{Patents and Cancer Prevention}

One of the important policy barriers to addressing cancer inequities concerns provisions for data exclusivity. Data exclusivity protects clinical trial data for a given period of time. Typically, the clinical trial data submitted by the innovator drug company is protected by separate data and market exclusivity periods that run parallel with the patent protection term. ${ }^{24}$ During the term when data exclusivity prevails, competing generic drug companies cannot rely on clinical trial data to get approval for follow-on products. Thus, the data cannot be submitted to gain approval for a generic drug from the US Food and Drug Administration (FDA). During the term of market exclusivity, the FDA accepts applications but does not grant market approval for a generic manufacturer's drug, thus ensuring additional monopoly protections for the drug. Thus, data and market exclusivities work as an additional layer of protection over patents.

For manufacturers of innovator pharmaceuticals, protection of clinical trial data provides an additional economic opportunity in that it creates a new market for the clinical trial data. In the United States, a biologics drug that is important for treating cancer or autoimmune diseases, for example, can benefit from 20 years of patent protection and an additional 4 years of data exclusivity and 8 years of market exclusivity, resulting in a guarantee of a total 
of 12 years of market exclusivity, ${ }^{25,26}$ and the FDA grants new chemical entities a total data exclusivity period of up to 5 years. ${ }^{27}$ The European Union currently allows 8 years of data exclusivity for the originator's preclinical and clinical test data. ${ }^{28}$ Pharmaceutical companies have slowly increased the period of data exclusivity, however. In the United States, in addition to data and market exclusivity, there is paediatric exclusivity that runs for 6 months and an orphan drug exclusivity that runs for 7 years. ${ }^{29}$ In fact, the United States had sought to extend exclusivity for data in its bilateral and regional agreements. For example, the United States-Mexico-Canada Agreement, sought a 10-year data exclusivity for new biologics, which would have represented an increase in the term of exclusivity for Mexico and Canada, ${ }^{30}$ although the final text approved on December 13, 2019, does not include the 10-year exclusivity requirement." 31

Importantly, extended data exclusivity periods may effectively provide market exclusivity for compounds that fail patent scrutiny and thus help maintain high pharmaceutical prices because even when a patent is declared invalid, access to data is unavailable for generics. So, if Company $A$ has a drug whose active ingredient is found unpatentable, the drug falls into the public domain and hence should be available to the generic drug manufacturer.

Nevertheless, on account of data exclusivity laws, the generic drug company will be prevented from using the clinical trial data to have its drug approved. Indirectly, this restriction results in awarding Company A market exclusivity even though it does not have any innovation in the market. Thus, with expensive medications such as cancer drugs, data exclusivity delays the entry of generic drugs into the market until the data protection period is over, and it indirectly allows the innovator pharmaceutical company to monopolize the market for even off-patent materials.

\section{Conflict Between Global Trade and Cancer}

A recent dispute under the WTO's dispute settlement process involving several nations highlights the intersection between patents and trademarks as well as the importance of domestic interventions to efficiently preserve public health. In the Australia plain packaging case, ${ }^{32}$ several countries disputed Australia's plain packaging laws. The law required that tobacco products not use logos, brand name, imagery, or promotional text on their packaging. The objective was to standardize the appearance of the packets to reduce the appeal of tobacco products and thereby prevent health consequences from smoking. The law is part of Australia's national comprehensive strategy to improve public health by reducing the use of, and exposure to, tobacco products. The complaining countries claimed that the 
plain packaging requirements restricted trade and violated key aspects of the TRIPS agreement-particularly, the companies' ability to protect and promote their trademarks. The complaint was that, in restricting the use of trademarks to preserve public health, Australia interfered with the IPs of the complainants. The WTO panel found that plain packaging requirements can and do make a meaningful contribution to Australia's objective of curbing tobacco use and exposure in order to prevent cancer despite its violation of trademark rights. ${ }^{32}$ The panel reiterated the importance of taking preventive measures to protect humans and prevent public health risks, given the extensive evidence of smoking as a key contributor to lung cancer. ${ }^{32}$

The Australian law provides a useful model for other countries interested in instituting such preventive measures. In fact, in 2016, the United Kingdom (UK) statutorily imposed plain packaging for tobacco products. The law came into force when the Supreme Court of the UK refused to consider an appeal by the tobacco industry against the law..$^{33}$ This case sheds light on how LMICs could align domestic public health objectives with emerging multilateral public health policies in the area of cancer prevention as well as cancer treatment.

\section{Conclusion}

The past decade's trade and patent policies have largely turned access to medication in LMICs into a luxury. Effective interventions for cancer treatment and prevention are thus needed in LMICs to reduce both human and financial costs of the cancer burden. Such interventions necessitate strategic policymaking and the inclusion of TRIPS flexibilities in proposed national legislation to enable the legislation's passage and efficient implementation. Although the inclusion of flexibilities in the TRIPS agreement has led to increased access to cancer medications, data and market exclusivity continues to pose impediments to access. It is therefore imperative that policies to prevent and treat cancer employ many-pronged approaches, which should involve both the medical and the trade community. Importantly, the medical community's interest in treating and preventing cancer should inform the global trade agenda. As interventions employed to tackle HIV/AIDS have shown, concerted and coordinated policy interventions can lead to desired results. The same should hold true for cancer. The bottom line is that the increased global incidence of cancer cries out for improved access to medications for cancer prevention and treatment.

\section{References}

1. World Health Organization. Latest global cancer data: cancer burden rises to 18.1 million new cases and 9.6 million cancer deaths in 2018 
[press release]. Geneva, Switzerland: World Health Organization; 2018. https://www.who.int/cancer/PRGlobocanFinal.pdf. Accessed November 8, 2019.

2. Prager GW, Braga S, Bystricky B, et al. Global cancer control: responding to the growing burden, rising costs and inequalities in access. ESMO Open. 2018;3(2):e000285.

3. Union for International Cancer Control. New global cancer data: GLOBOCAN 2018. https://www.uicc.org/news/new-global-cancerdata-globocan-2018. Updated June 7, 2019. Accessed November 18, 2019.

4. World Health Organization. Pricing of cancer medicines and its impacts.

https://apps.who.int/iris/bitstream/handle/10665/277190/9789241 515115-eng.pdf. Published 2018. Accessed July 21, 2019.

5. World Health Organization. Cancer. https://www.who.int/en/newsroom/fact-sheets/detail/cancer. Published September 12, 2018. Accessed July 21, 2019.

6. Kurian PK. The Compulsory License Application From M/S Natco Pharma Ltd. Mumbai, India: Indian Patent Office; 2011.

7. Wooldridge A. The battle for brainpower. Economist. October 7, 2006. https://www.economist.com/special-report/2006/10/07/the-battlefor-brainpower. Accessed July 22, 2019.

8. World Trade Organization. Agreement on trade-related aspects of intellectual property rights.

https://www.wto.org/english/docs_e/legal_e/27-trips.pdf. Effective January 1, 1995. Accessed December 11, 2019.

9. United Nations. Marrakesh Agreement establishing the World Trade Organization.

https://treaties.un.org/doc/Publication/UNTS/Volume\%201867/volu me-1867-I-31874-English.pdf. Adopted April 15, 1994. Accessed December 11, 2019.

10. World Trade Organization. Declaration on the TRIPS agreement and public health. 4rth WTO Ministerial Conference; November 9-14, 2001; Doha, Qatar. https://www.wto.org/english/thewto e/minist e/min01 e/mindecl _trips_e.htm. Adopted November 14, 2001. Accessed December 11, 2019.

11. World Health Organization. The Doha Declaration on the TRIPS agreement and public health. https://www.who.int/medicines/areas/policy/doha declaration/en/. Accessed November 8, 2019. 
12. TRIPS Agreement-Article 31 bis.

https://www.wto.org/english/res_e/publications_e/ai17_e/trips_ar t31_bis_oth.pdf. Accessed November 26, 2019.

13. Beall $R$, Kuhn R. Trends in compulsory licensing of pharmaceuticals since the Doha Declaration: a database analysis. PLoS Med. 2012;9(1):e1001154.

14. Bayer Corporation v Natco Pharma Ltd, Order No. 45/2013 (Intellectual Property Appellate Board, Chennai).

15. Lybecker K, Fowler E. Compulsory licensing in Canada and Thailand: comparing regimes to ensure legitimate use of the WTO rules. J Law Med Ethics. 2009;37(2):222-239.

16. Anh V. A shooting star for compulsory licensing: Thailand's licensing of medication for chronic diseases. In: Vanni A, Ragavan S, eds. Mapping the Three Generations of Struggle to Access to Medicines Under the TRIPS Agreement. New York, NY: Routledge. In press.

17. Stirner $B$, Thangaraj $H$. Learning from practice: compulsory licensing cases and access to medicines. Pharm Pat Anal. 2013;2(2):195-213.

18. Office of the United States Trade Representative. 2012 Special 301 report.

https://ustr.gov/sites/default/files/2012\%20Special\%20301\%20Repo rt_1.pdf. Published April 2012. Accessed October 2, 2019.

19. United Nations. Report of the United Nations Secretary General's High-Level Panel on Access to Medicines.

http://www.unsgaccessmeds.org/final-report. Published September 2016. Accessed October 2, 2019.

20. Beall R, Kuhn R. Trends in compulsory licensing of pharmaceuticals since the Doha Declaration: a database analysis. PLoS Med. 2012;9(1):e1001154.

21. Correa CM; South Centre. Pharmaceutical innovation, incremental patenting and compulsory licensing. http://apps.who.int/medicinedocs/documents/s21395en/s21395en. pdf. Published September 2011. Accessed October 2, 2019.

22. Azoulay P, Graff Zivin JS, Li D, Sampat BN. Public R\&D Investments and Private-Sector Patenting: Evidence from NIH Funding Rules. https://www.hbs.edu/faculty/Publication\%20Files/16056_cc35774b-e18c-4c18-b9c9-a8dd7c12225f.pdf. Harvard Business School working paper 16-056. Published September 3, 2015. Accessed October 3, 2019.

23. Ragavan $S$. The drug debate: data exclusivity is the new way to delay generics. Conn Law Rev Online. 2018;50. 
24. Ragavan $S$. The (re)newed barrier to access to medication: data exclusivity. Akron Law Rev. 2017;51(21):1163-1196.

25. Public Health Services Act, 42 USC §262(k) (2017).

26. Patient Protection and Affordable Care Act, Pub Law No. 111-148, $\S 7001$ Biologics Price Competition and Innovation Act of 2009, 124 Stat 119, 804 (2010).

27. Kimball J, Ragavan S, Vegas S. Reconsidering the rationale for the duration of data exclusivity [published online ahead of print October 5, 2019]. McGeorge Law Rev.

28. 't Hoen E, Boulet P, Baker B. Data exclusivity exceptions and compulsory licensing to promote generic medicines in the European Union: a proposal for greater coherence in European pharmaceutical legislation. J Pharm Policy Pract. 2017;10:19.

29. Federal Food, Drug, and Cosmetic Act, 21 USC §355(a) (2012).

30. Labonté R, Crosbie E, Gleeson D, McNamara C. USMCA (NAFTA 2.0): tightening the constraints on the right to regulate for public health. Global Health. 2019;15(1):35.

31. Office of the US Trade Representative. Agreement between the United States of America, the United Mexican States, and Canada 12/13/19 text. https://ustr.gov/trade-agreements/free-tradeagreements/united-states-mexico-canada-agreement/agreementbetween. Accessed December 16, 2019.

32. World Trade Organization. Dispute Settlement DS467: Australiacertain measures concerning trademarks, geographical indications and other plain packaging requirements applicable to tobacco products and packaging. https://www.wto.org/english/tratop_e/dispu_e/cases_e/ds467_e.h tm. Adopted August 27, 2018. Accessed July 25, 2019.

33. Johnston C. UK Supreme Court denies tobacco firms permission for plain packaging appeal. Guardian. April 11, 2017.

https://www.theguardian.com/society/2017/apr/11/uk-supremecourt-denies-tobacco-firms-permission-for-plain-packaging-appeal. Accessed July 25, 2019.

Srividhya Ragavan, SJD is a professor of law at the Texas A\&M University School of Law in Fort Worth and the author of Patents and Trade Disparities in Developing Countries (Oxford University Press, 2012). She served as a Fulbright Scholar in India and a Fulbright Specialist for the South Asia region. She received a BA LLB (honors) from the National Law School of India University in Bangolare, an LLM from King's College London, and an SJD from George Washington University Law School. 
Amaka Vanni, PhD is the author of the forthcoming Patent Games in the Global South: Pharmaceutical Patent Lawmaking in Brazil, India and Nigeria (Hart Publishing). She received a BA (honors) from Keele University and LLM and $\mathrm{PhD}$ degrees from the University of Warwick. Her doctoral thesis won the 2018 SIEL/Hart Prize for an outstanding unpublished manuscript by an early career scholar in the field of international economic law.

\section{Citation}

AMA J Ethics. 2020;22(2):E102-111.

DOI

10.1001/amajethics.2020.102.

\section{Conflict of Interest Disclosure}

The author(s) had no conflicts of interest to disclose.

The viewpoints expressed in this article are those of the author(s) and do not necessarily reflect the views and policies of the AMA.

Copyright 2020 American Medical Association. All rights reserved. ISSN 2376-6980 